\title{
PENGARUH STRUCTURE OWNERSHIP DAN KARAKTERISTIK AUDITOR TERHADAP TAX AVOIDANCE PADA PERUSAHAAN DALAM IDXV30 DI BURSA EFEK INDONESIA
}

\author{
Rahadian Cahyadi \\ rahadiancahyadi002@gmail.com \\ Fadliah Nasaruddin \\ fadliah.nas@gmail.com \\ Darwis Lannai \\ dlannai759@gmail.com \\ Megister Akuntansi \\ Universitas Muslim Indonesia
}

\section{Abstract}

This study aims to determine the effect of Structure Onwership and Auditor Characteristics on Tax Avoidance in IDXV30 on the Indonesia Stock Exchange. This study uses a quantitative method with the acquisition and secondary data collection. The companies that became the sample of this study were 30 companies that applied accounting conservatism. The number of samples that could be analyzed were 30 samples, thus the number of samples over three years was 90 samples (30x3). The results of the X1 Variable Test (Structure Ownership) gave a parameter coefficient ( $t$-count) of 1,809 with a significance level of $0.07(<0.10)$. This means that H1 is accepted (Hair, 2017) so it can be said that Structure Ownership has a positive and significant effect on Tax Avoidance Variable X2 (Characteristics of Auditors) giving a parameter coefficient value of $0.02(<0.05)$. This means that H1 is accepted so that it can be said that the auditor's characteristics have a significant and significant effect on tax avoidance because the level of significance possessed by the auditor's variable characteristics $<0.05(0.02>0.05)$ and tcount $>1.668(2,347>1,668)$.

Key words : Ownership and Structure, Auditor Characteristics

\begin{abstract}
Abstrak
Penelitian ini bertujuan untuk mengetahui pengaruh Structure Onwership dan Karakteristik Auditor terhadap Tax Avoidance dalam IDXV30 di Bursa Efek Indonesia. Penelitian ini menggunakan metode kuantitatif dengan perolehan dan pengumpulan data sekunder Perusahaan yang menjadi sampel penelitian ini adalah 30 perusahaan yang menerapkan konservatisme akuntansi.jumlah sampel yang dapat dianalisa sebanyak 30 sampel, dengan demikian jumlah sampel selama tiga tahun sebanyak 90 sampel (30x 3). Hasil dari Pengujian Variabel X1 (Structure Ownership) memberikan nilai koefisien parameter (t-hitung) sebesar 1.809 dengan tingkat signifikansi 0,07 $(<0,10)$. Hal ini berarti H1 diterima (Hair, 2017) sehingga dapat dikatakan bahwa Structure Ownership berpengaruh Positif dan signifikan terhadap Tax Avoidance Variabel X2 (Karateristik Auditor) memberikan nilai koefisien parameter sebesar dengan tingkat signifikansi $0,02(<0,05)$. Hal ini berarti H1 diterima sehingga dapat dikatakan bahwa karateristik auditor berpengaruh psotif dan signifikan terhadap tax avoidance karena tingkat signifikansi yang dimiliki variabel karateristik auditor $<0,05(0,02>0,05)$ dan nilai thitung $>1.668(2.347>1,668)$.
\end{abstract}

Kata Kunci: Structure Ownership dan, Karakteristik Auditor 


\section{PENDAHULUAN}

Perusahaan merupakan sebuah bentuk dari entitas bisnis yang mempunyai tujuan serta memiliki langkah besar dan perusahaan merupakan sebuah upaya dan memiliki visi strategis dan jangka panjang dalam perencananaan jangka panjang, Perusahaan harus mampu mempertanggungjawbakan dalam sebuah laporan pertanggungjawaban dalam pembuatan laporan keuangan serta kedepan perusahaan dapat di audit oleh seorang auditor dari kantor akuntan publik, maka perusahaan dapat membuktikan laporan tersebut dan dari hasil laporan audit terutama dari perolehan pajak yang dibuat dalam pelaporan pajak serta pembayaran pajak yang harus setiap periode tertentu untuk dapat dibayarkan serta perusahaan dalam hal pembayaran pajak menjadi kewajiban dari sebuah perusahaan dalam segala bentuk konsekuensi dari keberlangsungan dari pembuatan laporan keuangan dari segi pelaporan pajak. Pembayaran pajak dari perusahaan menjadi salah satu bentuk kontribusi real perusahaan agar dapat mampu dikelola dengan baik oleh perusahaan setiap tahun pada periode yang akan di optimalkan dari sebuah struktur kepemilikan perusahaan dan menjadi perusahaan yang baik.

Perusahaan tidak hanya didirikan tanpa memiliki struktur dan tujuan yang tidak jelas namum dari segi kepemilikam serta tujuan yang harus dicapat ada banyak hal yang bersinggungan dengan Structure Ownership mulai dari pendirian, struktur perusahaan, dan laporan keuangan berupa komponen laporan keuangan agar dapat dibuat dan dapat diberikan pemahaman dari laporan pajak dari sebuah perusahaan dan akan dapat bersaing dengan perusahaan lain dan menjadi perusahaan yang baik. (Darwis, 2012).

Fenomena yang terjadi dari peristiwa pada tahun 2016 telah terjadi peristiwa besar yang berdampak dengan terjadinya peristiwa yang mengubah wajah dunia karena terjadi sebuah kebocoran data keuangan dengan skala besar dan peristiwa besar itu adalah merupakan peristiwa kebocoran data keuangan dari sebuah Firma hukum Mossack Fonseca yang berasal dari panama dan dari hasil temuan pers dan dari pemberitaan pada waktu itu yang terkait dengan temuan yang dia peroleh bahwa temuan dari kebocoran data keuangan di negara panama tersebut yaitu offshore (tax haven countries) lebih dari 214 unit perusahaan dan perusahaan dalam dunia offshare telah mengalirkan uang yang digelapkan dengan mencuri kekayaan negara dari pajak yang tidak dibayarkan, namum kenyataan dari pendirian dari sebuah perusahan yang tergabung di dunia offshare tidak melawan hukum sebenarnya tujuan dari semua itu adalah perusahaan yang didirikan berdasarkan aturan hukum yang benar namun telah melakukan transaksi yang fiktif dapat melakukan sebuah usaha sebagai penghindar pajak (Tax Avoidance).

Tax Avoidance ini membuat perusahaan sebagai sebuah entitas usaha dengan semata-mata meperoleh keuntungan dari perusahaan dalam bentuk pelaporan keuangan serta upaya dalam penghindaran pajak (Tax Avoidance) tidak hanya satu negara namum melibatkan di negara lain tentu ada negara yang memberikan perlindungan pajak untuk praktik penghindaran pajak seperti di Panama, 
Barbados, Hongkong dan British Virgin Islands (Chen S, 2010).

Tax Avoidance merupakan kasus yang telah ditemui di indonesia dan sudah diproses oleh Direktorat Jenderal Pajak (DJP) salah satu kasus yaitu kasus Asian Agri, Bumi Resources, Adaro, Indosat, Indofood, Kaltim Promotion Coal (KPC) dan Terakhir PT. Airfast Indonesaia (anak perusahaan dari (PT. Freeport Mc Moran) hal ini menunjukkan dari temuan fakta bahwa kejadian diatas yang dialami oleh perusahaan besar dan skala multinasional yang memiliki nilai aset (Firm Size) yang besar penerimaan pajak dari perusahaan multinasional mengindikasikan adanya upaya untuk melakukan penghindaran pajak secara besar-besaran dalam pendapatan dari perusahan tersebut yang memiliki nilai aset yang besar (Kemenkeu, 2017).

Indonesia memiliki program Tax Amnesty menunjukkan rendahnya kesadaran wajib pajak di negara Indonesia, dalam memenuhi kewajiban pajak baik wajib pajak badan maupun orang pribadi akibat yang ditimbukan adalah upaya penghindaran pajak (Tax Avoidance), serta praktiknya semakin marak terjadi, Indonesia yang memiliki perusahaan dengan tingkat pajak yang sangat besar salah satu upaya yang dilakukan adalah untuk melakukan penghindaran pajak dengan yang akan dilakukan Indonesia terdapat lima kategori Strucutre Ownership yang umum di temukan yakni kepemilikikan oleh pribadi, kepemilikan institusional, kepemilikan manajer, kepemilikan asing dan kepemilikan secara independen dan bukan dari pihak tertentu, Sebagai perusahaan yang baik setidaknya perlu memiliki tanggung jawab dalam hal yang yang terjadi apabila struktur kepemilikan dari perusahaan tidak memiliki bentuk serta tujuan yang tidak terarah serta peran yang mengatur bentuk dari struktur kepemilikan serta pendirian dari perusahaan.

Beberapa penelitian menunjukkan bahwa dalam kepemilikan perusahaan ada yang mempengaruhi hal pertama yang berpengaruh dari segi kepemilikan perusahaan terhadap pengendalian serta pengelolaan perusahaan, Dalam hal ini Structure Ownership mampu mempengaruhi perusahaan dalam menunjang kinerja perusahaan untuk mencapai tujuan perusahaan kedepan, Perusahaan perlu melakukan pengawasan serta pengelolaan perusahaan serta mengevaluasi apakah perusahaan tersebut sudah baik atau belum dikelola dengan tepat.

Perusahaan yang ada di Indonesia saat ini merupakan sebuah perusahaan terkait dengan salah satu perusahaan yang terjadi pemberitaan serta isu yang sering muncul dalam Corporate Governance adalah mengenai Struktur Kepemilikan (Structure Ownership) yang paling sering menjadi permsalahan adalah dari segi pengukuran dari kinerja perusahaan karena perusahaan begitu banyak ditemukan dalam permasalahan yang ada di dalam perusahaan yang terjadi dalam posisi yang tidak baik dalam hal keuangan serta bentuk pertanggungjawaban, Perusahaan tentunya harus memiliki sebuah komitmen yang baik dari perusahaan selama ini terjadi antara pemilik perusahaan dengan pengelola perusahaan dengan permasalahan internal langkah bentu kepemilikan diambil untuk dapat menyelamatkan perusahaan dari kebangkrutan permasalahan keuangan yang akan terjadi di masa mendatang (Yasser Q. M., 2017) 
Penelitian ini akan dilakukan pada perusahaan yang ada di Bursa Efek Indonesai. Hal yang menjadi fokus penelitain yaitu faktor dari 30 perusahaan yang masuk dalam IDX Value30 (IDXV30) dalam pelaporan keuangan serta pelaporan pajaknya dapat dijadikan poulasi dan perolehan sampel yang akan diambil dari perusahaan tersebut dapat diambil sampel laporan keuangan yang diambil dari laporan keuangan yang akan diambil serta apakah salah satu upaya dari perusahaan yang terdaftar di Bursa Efek Indonesia di IDXV30 tersebut apakah ada cara untuk melakukan penghindaran pajak (Tax Avoidance) (Winata, 2014)

\section{TINJAUAN PUSTAKA}

\subsection{Teori Keagenan (Theory Agency)}

Teori Agensi adalah teori yang terjadi antara satu atau lebih yang melibatkan individu dari organisasi yang berperan sebagai penyedia jasa dan memiliki kewenangan untuk membuat sebuah keputusan Siregar (2005:85) dalam Struktur kepemilikan dapat dipisah untuk memaksimalkan perusahaan dalam bentuk kepemilikan, Dengan teori diatas maka permasalahan dan fenomena yang terjadi pada perusahaan yang ada di indonesia untuk mengukur serta melihat Structure Ownership yang dikemukakan oleh Siagian (2011:35)

\subsection{Tax Avoidance}

Tax Avoidance adalah salah satu upaya upaya yang dilakukan manajemen dalam perusahaan untuk melakukan penghindaran pajak (tax avoidance) upaya ini dilakukakan untuk menghindari pembayaran pajak namun secara perudang-undangan atau ketentuan yang berlaku secara legal bagi wajib pajak karena tidak bertentangan dengan undang-undang dan peraturan yang berlaku, karena upaya yang digunakan dengan mencari kelemahan-kelemahan (grey area) yang terdapat dalam perundang-undangan dan peraturan pajak untuk memperkecil pajak terutang yang terjadi dalam perusaan Pohan (2013:68).

\subsection{Teori Structure Ownership}

Perusahaan merupakan salah satu bentuk pendidirian dari usaha yang didalamnya memiliki bentuk kepemilikan dari pelaksanaan fungsi dalam pengelolaan perusahaan karena adanya perencanaan serta upaya besar yang akan dilaksanakan dalam mendirikan perusahaan dengan kondisi terbatas karena adanya keterbatasan dan bentuk kerjasama antara berbagai pihak untuk dapat menjalankan perusahaan sesuai dengan apa yang diharapkan dengan tujuan yang akan dicapai.

Structure Ownership yang dimaksud adalah salah satu contoh bentuk kepemilikan dari sebuah perusahaan yang dikelola oleh manajer dan pelaksana serta pemegang saham yang menyertakan dan meberikan modal untuk keberlangsungan perusahaan sedangkan manajer adalah pihak yang bertanggungjawab dan diberi kewenangan penuh dalam penentuan kebijakan dalam pengambilan keputusan yang ada di perusahaan Sudana (2011:38).

\subsection{Karakteristik Auditor}

Audit merupakan sebuah solusi yang baik untuk mengambil langkah strategis untuk menyelamatkan perusahaan dari permasalahan laporan keuangan dan proses audit itu dilakukan oleh seorang auditor yang ada dalam perusahaan maupun dari Kantor Akuntan Publik (KAP) dan bertugas untuk memeriksa laporan keuangan merupakan tugas dari seorang Auditor untuk 
memperbaiki kesalahan atau kekeliruan dari kualitas laporan keuangan dengan mengawasi seluruh aktifitas keuangan dan perusahaan tersebut mampu menyajikan laporan keuangan secara baik atau diterima secara wajar saat proses audit sesuai dengan prinsip akuntansi yang berlaku secara umum KNKG (2006:145).

\subsection{Perusahaan IDXV30 di Bursa Efek Indonesia (BEI)}

Penelitian ini memfokuskan pada objek pengambilan sampel penelitian dengan mengambil dari pada salah satu sektor perusahaan, kelompok perusahaan yang terdaftar di Bursa Efek Indonesia (BEI) yang masuk dalam daftar IDX Value30 (IDXV30), dan IDX Value30 (IDXV30) adalah 30 saham perusahaan yang memiliki valuasi harga yang rendah dengan likuiditas transaksi serta kinerja keuangan yang baik yaitu perusahaan besar karena Perusahaan $r$ merupakakan perusahaan yang seluruh seluruh aktivitas bentuk produksi sebagian usahanya penjualan terkait dengan aspek perpajakan yang dapat dilihat. Perusahaan ini memiliki jumlah perusahaan yang menjadi fokusdari seluruh perusahaan karena perusahaan ini dapat ditemukan dengan usaha dari perusahaan dalam menjalankan aktifitas.

\subsection{Tax Avoideance Perusahaan IDXV30 di Bursa Efek Indonesia (BEI)}

Bursa Efek Indonesia menjadi salah sebuah pasar yang berhubungan dengan pembelian dan penjualan Stock Exchange dalam yang menjadi Perusahaan Besar terutama yang masuk dalam Indeks yang ada di IDXv30 merupakan sumber utama permodalan eksternal bagi perusahaan dalam perdangangan saham dimana perusahaan yang masuk ke dalam IDXV30 ini bukan perusahaan kecil karena perusahaan yang ada dalam indeks ini merupakan perusahaan yang menjadi turunan dari LQ45 dan indeks ini terfokus pada 30 perusahaan yang dari segi ketahanan dari perusahaan mampu menjaga stabilitas serta kapitalisasi di pasar dalam menjadi nilai dari saham yang ada di pasar modal menjadi salah satu opsi bagi investor.

\section{METODE PENELITIAN}

\subsection{Desain Penelitian}

Pada penelitian ini akan menggunakan metode kuantitatif dan penelitian menggunakan data sekunder yang diperoleh dari Objek penelitian berupa data pendukung yang berkaitan dengan kebutuhan data yang akan diambil pada saat penelitian. Data sekunder yang dimaksud adalah Data yang diperoleh dari sumber Data yang dikumpulkan melalui berbagai laporan yakni laporan pajak yang berdasarkan laporan keuangan dan data pendukung yang relevan dengan pengambilan data Berdasarkan data hasil penelitian yang telah terkumpul, dilakukan uji verifikasi untuk menguji hipotesis yang telah dirumuskan sebelumnya.Unit analisis yang diteliti adalah Struktur Kepemilikan (structure ownership), Kualitas Auditor perusahaan dan Tax Avoidance dengan menggunakan perusahaan di Bursa Efek Indonesia yang masuk dalam daftar IDX Value30 (IDXV30).

\subsection{Lokasi Dan Waktu Penelitian}

Lokasi penelitian ini dilakukan di Bursa Efek Indonesia, data diperoleh dengan mengakses www.idx.co.id dan dari Pusat Referensi Pasar Modal (PRPM) serta menggunakan data pada Indonesian Capital Market Directory (ICMD). Perusahaan sampel yang digunakan 
adalah fokus ke perusahaan manufaktur. Waktu penelitian akan dilaksanakan pada selama Dua bulan di Bursa Efek Indonesia (BEI).

\subsection{Jenis dan Sumber Data}

\section{Jenis Data}

Berdasarkan jenisnya, data yang disajikan dalam penelitian ini adalah data kuantitatif. Data kuantitatif adalah data laporan keuangan serta data keuangan dari catatan atas laporan keuangan pada perusahaan manufaktur yang terdaftar di Bursa Efek Indonesia (BEI) yang masuk dalam daftar IDX Value30 (IDXV30).

2. Sumber Data

Menurut sumbernya, data yang digunakan dalam penelitian ini adalah data sekunder eksternal yaitu data yang diperoleh secara tidak langsung melalui perantara, seperti orang lain atau dokumen. Adapun data yang digunakan dalam penelitian ini adalah data laporan keuangan dan catatan atas laporan keuangan perusahaan yang dapat diajadikan sampel, yang diperoleh dari Bursa Efek Indonesia (BEI).

3. Populasi dan Teknik Sampel

Populasi dalam penelitian ini adalah perusahaan manufaktur yang terdaftar di Bursa Efek Indonesia. Perusahaan yang menjadi sampel penelitian ini adalah perusahaan yang masuk dalam daftar IDX Value30 (IDXV30) dan menerapkan Struktur Kepemilikan , Karakteristik Auditor dan Tax Avoidance Pengambilan sampel dipilih dengan metode purposive sampling, di mana pemilihan sampel perusahaan didasarkan pada kriteria tertentu. Sampel pada penelitian ini dipilih dari populasi yang memenuhi kriteria sebagai berikut:

a) Perusahaan Manufaktur yang terdaftar di Bursa Efek Indonesia (BEI) tahun 2016-2018 yang masuk dalam daftar
IDX Value30 (IDXV30). IDX Value30 (IDXV30) adalah 30 saham yang memiliki valuasi harga yang rendah dengan likuiditas transaksi serta kinerja keuangan yang baik.

b) Memiliki laporan keuangan yang telah diaudit oleh kantor akuntan publik untuk tahun yang berakhir 31 Desember berupa catatan atas laporan keuangan yang diperoleh dari laporan keuangan perusahaan.

4. Instrumen Pengumpulan Data

Dalam penelitian ini pengumpulan data dilakukan dengan teknik Data laporan keuangan tahunan, yaitu dengan mengumpulkan data yang berhubungan dengan penelitian Penelitian ini menggunakan sumber data sekunder. Data sekunder umumnya berupa bukti, catatan atau laporan historis yang telah tersusun dalam arsip (data dokumenter) yang dipublikasikan dan yang tidak dipublikasikan Bambang Supomo (2009:176) Data diperoleh dari laporan keuangan tahunan perusahaan manufaktur yang masuk dalam IDX Value30 (IDXV30) yang terdaftar di Bursa Efek Indonesia dan ICMD dari tahun 2016-2018.

5. Defenisi Operasional dan Pengukuran Variabel

a. Variabel Independen

Tabel 4.1

Operasional Variabel Independen

\begin{tabular}{|l|l||l||}
\hline Variabel & Indikator & Skala \\
\hline \hline $\begin{array}{l}\text { Struktur } \\
\text { Kepemilikan } \\
\text { (Structure }\end{array}$ & $\begin{array}{l}\text { 1.Kepemilikan Institusional } \\
\text { Ownership) } \\
\text { (X1) }\end{array}$ & (Mei Yuniarti,2016) \\
$\begin{array}{l}\text { Karakteris tik } \\
\text { Auditor }\end{array}$ & 1. Lama berdirinya Kantor Akuntan Publik (KAP). & \\
(X2) & 2. Fee Audit. & Nominal \\
(Ninik, 2017) & \\
\hline
\end{tabular}

1. Structure Ownership

Structure Ownership adalah proporsi kepemilikan manajemen, kepemilikan institusional, dan kepemilikan publik dan struktur kepemilikan merupakan suatu 
mekanisme untuk mengurangi konflik antara manajemen dan pemegang saham dengan kepemilikan institusondal (Mei Yuniarti,2016).

2. Karaktersitik Auditor

Karakteristik auditor ini menggambarkan ciri dari seorang auditor dilihat dari Penugasan dari Kantor Akuntan Publik dan telah berpengalaman dalam menerima tugas melakukan Audit pada sebuah laporan keuangan dan keahliannya pada suatu perusahaan. Auditor yang dianggap memiliki karakteristik adalah Auditor yang ditugaskan dalam pelaksanaan audit yang berasal dari Kantor Akuntan Publik dan hasil audit laporan keuangan apabila telah seleseai dan diberikan Fee Audit dari perusahaan. Karakteristik auditor diukur menggunakan skala nominal. (Ninik, 2017).

b. Variabel Dependen

Tabel 1.4

Operasional Variabel Dependen

\begin{tabular}{|l||l||l||}
\hline Variabel & Indikator & Skala \\
\hline Tax \\
Avoidance \\
(Y)
\end{tabular}

Menurut Sugiyono (2015:48) variabel dependen sebagai berikut: Variabel terikat merupkan variabel yang dipengaruhi atau yang menjadi akibat, karena adanya variabel bebas.Dalam penelitian ini yang menjadi variabel dependen ( $\mathrm{Y}$ ) adalah Tax Avoidance. Menurut (Budiman, 2012) penghindaran pajak merupakan usaha yang dilakukan wajib pajak untuk mengurangi beban pajak dengan tidak melanggar undangundang atau aturan lain yang berlaku. Pengukuran Tax Avoidance menggunakan
CETR yaitu dengan membagi kas yang dikeluarkan untuk biaya pajak dibagi dengan laba sebelum pajak.

$$
\text { Cash ETR }=\frac{\text { Pembayaran Pajak }}{\text { Laba Sebelum Pajak }}
$$

Tax Avoidance dalam penelitian ini diukur dengan menggunakan skala nominal, yaitu 1 melakukan penghindaran pajak dan 0 tidak melakukan pengindaran pajak. Perusahaan dikategorikan melakukan penghindaran pajak apabila Cash Effective Tax Rate (CETR) kurang dari 25\%, dan apabila Cas Effective Tax Rate (CETR) lebih dari 25\% dikategorikan tidak melakukan penghindaran pajak.

\subsection{Metode Analisis Data}

Data yang telah terkumpul dilakukan analisis regresi linear berganda (Multiple Linear Regression) dengan bantuan program SPSS 21.0 for windows. Hasil penelitian berupa uji asumsi klasik, analisis regresi berganda, dan teknik pengujian hipotesis.

1. Uji Asumsi Klasik

Sebelum melakukan pengujian menggunakan uji regresi linear berganda, terlebih dahulu data harus memenuhi syarat asumsi klasik, yang meliputi uji normalitas, uji multikolinearitas, dan uji heteroskedastisitas.

\section{Uji Normalitas}

Uji normalitas bertujuan untuk menguji apakah dalam model regresi, variabel terikat dan variabel bebas keduanya mempunyai distribusi normal ataukah tidak. Pada prinsipnya normalitas dapat dideteksi dengan melihat penyebaran data (titik) pada sumbu diagonal dari grafik atau dengan melihat histogram dari residualnya. Dasar pengambilan keputusan:

a) Jika data menyebar disekitar garis diagonal dan mengikuti arah garis 
diagonal atau grafik histogramnya menunjukkan pola distribusi normal, maka model regresi memenuhi asumsi normalitas.

b) Jika data menyebar jauh dari garis diagonal dan atau tidak mengikuti arah garis diagonal atau grafik histogram tidak menunjukkan pola distribusi normal, maka model regresi tidak memenuhi asumsi normalitas.

Uji statistik lain yang dapat digunakan untuk menguji normalitas residsual adalah uji statistik nonparametrikkolmogorov-smirnov (K-S). Uji kolmogorov smirnov adalah uji beda antara data yang diuji normalitasnya dengan data normal baku. Penerapan pada uji kolmogorov smirnov adalah bahwa jika signifikansi di bawah 0,05 berarti data yang akan diuji mempunyai perbedaan yang signifikan dengan data normal baku, berarti data tersebut tidak normal. Lebih lanjut, jika signifikansi di atas 0,05 maka berarti tidak terdapat perbedaan yang signifikan antara data yang akan diuji dengan data normal baku, atau data berdistribusi normal.

\section{Uji Multikolinearitas}

Uji multikolinearitas bertujuan untuk menguji apakah pada model regresi ditemukan adanya korelasi antar variabel independen. Model regresi yang baik seharusnya tidak terjadi korelasi diantara variabel variabel independen. Jika variabel-variabel saling berkorelasi, maka variabel-variabel ini tidak ortogonal. Variabel ortogonal adalah variabel bebas yang nilai korelasi antar sesama variabel bebas adalah nol. Untuk mendeteksi ada atau tidaknya multikolinearitas di dalam model regresi adalah sebagai berikut:

a) Nilai R2 yang dihasilkan oleh suatu estimasi model regresi empiris sangat tinggi, tetapi secara individual variabel-variabel bebas banyak yang tidak signifikan mempengaruhi variabel terikat.

b) Menganalisis matrik korelasi variabelvariabel bebas. Jika antar variabel bebas ada korelasi yang cukup tinggi (diatas 0,90) maka hal ini merupakan indikasi adanya multikolinearitas.

c) Multikolinearitas dapat juga dilihat dari tolerance value dan variance inflation factor (VIF). Batas tolerance value adalah 0,10 dan VIF adalah 10 . Apabila nilai tolerance value kurang dari 0,10 atau VIF lebih besar dari 10 maka terjadi multikolinearitas.

\section{Uji Heteroskedastisitas}

Uji Heteroskedastisitas bertujuan menguji apakah dalam model regresi terjadi ketidaksamaan variance dari residual satu pengamatan ke pengamatan yang lain. Jika variance dari residual suatu pengamatan ke pengamatan yang lain tetap maka disebut homoskedastisitas dan jika berbeda disebut heteroskedastisitas. Model regresi yang baik adalah yang terjadi homoskedastisitas atau tidak terjadi heteroskedastisias. Untuk mendeteksi ada atau tidaknya heteroskedastisitas yaitu dengan melihat grafik plot antara nilai prediksi variabel terikat (ZPRED) dengan residualnya (SRESID), yaitu dengan deteksi ada tidaknya pola tertentu pada grafik scaterplot antara SRESID dan ZPRED. Dasar analisisnya adalah sebagai berikut:

a) Jika ada pola tertentu, seperti titik yang ada membentuk pola tertentu yang teratur, maka mengindikasikan telah terjadi heteroskedastisitas.

b) Jika tidak ada pola yang jelas, serta titik-titik menyebar diatas dan 
dibawah angka 0 dan sumbu $Y$, maka tidak terjadi heteroskedastisitas.

Kemudian uji heterokedastisitas juga dapat dilakukan dengan melakukan uji glesjer. Uji ini dilakukan dengan meregres nilai absolut residual terhadap variabel independen. Jika variabel independen signifikan secara statistik mempengaruhi variabel dependen, maka ada indikasi terjadi heteroskedastisitas.

\section{Model Regresi}

Analisis yang digunakan dalam penelitian ini adalah analisis regresi linear berganda (multiple linear regression) dengan menggunakan program SPSS 21.0 for windows. Model regresi yang digunakan dapat dirumuskan dengan persamaan berikut ini.

$$
\mathrm{TA}=\alpha+\beta 1 \mathrm{X} 1+\beta 2 \mathrm{X} 2+\varepsilon
$$

Keterangan:

$\begin{array}{ll}\text { TA } & : \text { Tax Avoidance } \\ \alpha & : \text { Konstanta } \\ \beta & : \text { koefisien regresi } \\ \mathrm{X} 1 & : \text { Struktur Kepemilikan } \\ \mathrm{X} 2 & : \text { Karakteristik Auditor } \\ \varepsilon & : \text { eror }\end{array}$

Analisis regresi linier berganda disamping untuk mengukur kekuatan hubungan antara dua variabel atau lebih juga menunjukkan arah hubungan antara variabel dependen dengan independen, Jadi analisis regresi berganda merupakan analisa untuk mengukur seberapa besar pengaruh variabel Structure Ownership dan karakteristik auditor terhadap Tax Avoidance pada perusahaan yang masukd dalam IDXV30 di Bursa Efek Indonesia.

Apabila koefisien $\beta$ bernilai positif $(+)$ maka terjadi pengaruh searah antara variabel independen dengan variabel dependen, demikian pula sebaliknya, bila koefisien $\beta$ bernilai negatif $(-)$ hal ini menunjukkan adanya pengaruh negatif dimana kenaikan nilai variabel independen akan mengakibatkan penurunan nilai variabel dependen.

6. Teknik Pengujian Hipotesis

Koefisien determinasi (R2) pada intinya mengukur seberapa jauh kemampuan model dalam menerangkan Variasi-variabel terikat, Nilai koefisien determinasi adalah diantara nol dan satu. Nilai R2 yang celi berarti kemampuan variabel-variabel independen dalam menjelaskan variasi variabel dependen amat terbatas. Nilai yang mendekati satu berarti variabel-variabel independen memberikan hampir semua informasi yang dibutuhkan untuk memprediksi variasi variabel dependen.

a) Uji Statistik $t$

Uji t-Statistik Pengujian yang dilakukan ini untuk mengetahui signifikan tidaknya pengaruh masing-masing variabel secara individual (parsial) terhadap sebuah variabel terikat. Pengujian ini dilakukan dengan membandingkan thitung dengan $t$ tabel (Ghozali I. , 2011).

- Jika thitung < t tabel atau nilai signifikan uji $t>0,05$ maka Ho diterima, yang artinya variabel bebas yang diuji secara parsial mempunyai pengaruh terhadap variabel terikat.

- Jika thitung $>\mathrm{t}$ tabel atau nilai signifikan uji $t<0,05$ maka Ho ditolak, yang artinya variabel bebas yang diuji secara parsial mempunyai pengaruh terhadap variabel terikat.

Uji t digunakan untuk mengetahui pengaruh masing-masing variabel independen terhadap variabel dependen. Jika nilai signifikan uji $\mathrm{t}<0,05$ atau $\mathrm{F}$ hitung > F tabel maka pengaruh terhadap variabel bebas $(\mathrm{X})$ secara simultan 
terhadap variabel terikat (Y). Jika nilai signifikan uji $t>0,05$ atau $F$ hitung $<F$ tabel maka pengaruh terhadap variabel bebas (X).

\section{Uji Statistik F}

Uji F (Hipotesis Koefisien Secara Menyeluruh) Pengujian ini bertujuan untuk melihat signifikan tidaknya pengaruh variabel bebas secara bersamasama (stimultan) terhadap variabel terikat. Pengujian ini dilakukan dengan membandingkan $\mathrm{F}$ hitung dengan $\mathrm{F}$ tabel a. Jika $\mathrm{F}$ hitung $\leq \mathrm{F}$ tabel atau nilai signifikan uji $\mathrm{F}>0,05$ maka Ho diterima, artinya variabel-variabel bebas secara simultan tidak berpengaruh terhadap variabel terikat. b. Jika F hitung $>$ tabel atau nilai signifikan uji $\mathrm{F}<0,05$ maka Ho ditolak, artinya variabel-variabel bebas secara simultan berpengaruh terhadap variabel terikat.

Pengujian berganda (serempak) dengan melakukan uji $\mathrm{F}$ hitung, dengan mencari besarnya $\mathrm{F}$ hitung yang akan dibandingkan dengan $\mathrm{F}$ tabel. Pengujian $\mathrm{F}$ hitung digunakan untuk mengetahui kualitas keberartian regresi antara tiaptiap variabel bebas (X) secara serempak/bersamaan terdapat pengaruh atau tidak terhadap variabel terikat $(\mathrm{Y})$ Kriteria Pengujian (Ghozali I. , 2011):

- Jika nilai signifikan $>0,05$, atau $\mathrm{F}$ hitung > F tabel maka Ho diterima, artinya variabel variabel bebas secara simultan berpengaruh terhadap variabel terikat.

- Jika nilai signifikan $>0,05$, atau $\mathrm{F}$ hitung < F tabel maka Ho ditolak, artinya variabel variabel bebas secara simultan tidak berpengaruh terhadap variabel terikat.

\section{HASIL DAN PEMBAHASAN}

\subsection{Hasil Penelitian}

1. Uji Asumsi Klasik

a. Uji Normalitas Data

Uji normalitas data dilakukan untuk melihat bahwa suatu data terdistribusisecara normal atau tidak. Uji statistik yang digunakan untuk menguji apakah residual berdistribusi normal adalah dengan uji statistik non parametrik Kolmogorov-Smirno (K-S). Cara mendeteksinya adalah dengan melihat nilai signifikansi residual, jika signifikansi lebih dari 0,05 maka residual terdistribusi secara normal. berikut ini gambar grafik uji normalitas data pada grafik Kolmogorov-Smirno (K-S).

\begin{tabular}{|c|c|c|c|c|}
\hline One-Sample Kolmogorov & $\begin{array}{r}\text { Hasil U } \\
\text { v-Smirnov Tes }\end{array}$ & $\begin{array}{l}\text { Tabel } 2 \\
\text { Normalitas Data }\end{array}$ & & \\
\hline & & \begin{tabular}{|l|} 
Structure \\
Ownership
\end{tabular} & \begin{tabular}{|l}
$\begin{array}{l}\text { Karateristik } \\
\text { Auditor }\end{array}$ \\
\end{tabular} & \begin{tabular}{|l|l} 
Tax \\
Avoidance
\end{tabular} \\
\hline $\mathrm{N}$ & & 90 & 90 & 90 \\
\hline & Mean & ,7803 & 12,8836 & 4333 \\
\hline Normal Parametersa,b & $\begin{array}{l}\text { Std. } \\
\text { Deviation }\end{array}$ & ,73262 & 3,69220 & 49831 \\
\hline Most Extreme & Absolute & ,315 & 134 & ,374 \\
\hline Differences & Positive & 315 & 134 & ,374 \\
\hline & Negative & 164 & -078 &,- 306 \\
\hline Kolmogorov-Smirnov Z & & 2,993 & 1,269 & 3,552 \\
\hline Asymp. Sig. (2-tailed) & & ,000 & ,080 & ,000 \\
\hline
\end{tabular}

Dapat dilihat pada tabel tersebut bahwa data diperoleh besarnya nilai Asymp Sig. (2.tailed) sebesar 0,000<0,05, maka residual berdistribusi Tidak normal untuk X1, 0,080>0,05, maka residual berdistribusi normal untuk X2 dan $0,000<0,05$, maka residual berdistribusi Tidak normal untuk X3.

\section{b. Uji Multikolinearitas}

Uji multikolinieritas adalah uji yang dilakukan untuk menguji apakah dalam model regresi ditemukan adanya korelasi antar variabel independen. Cara yang dilakukan untuk melihat ada tidaknya multikolinieritas adalah dengan melihat nilai tolerance dan VIF.Menurut imam Ghozali (2011:107-108), tidak terjadi 
gejala multikolonieritas, jika nilai tolerance $>0,10$ dan VIF $<10,00$.

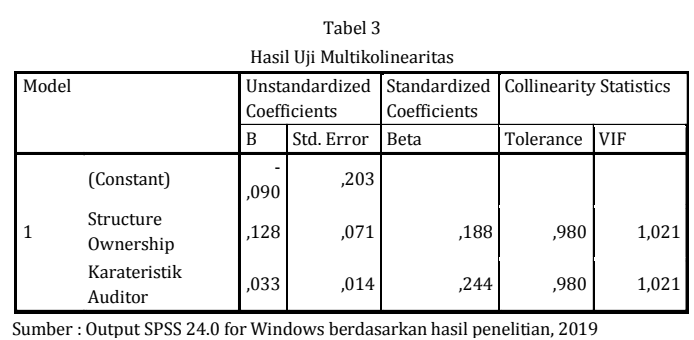

Dari tabel diatas dapat dilihat bahwa tidak ada variabel yang memiliki nilai tolerance $>0,10$ dan nilai VIF $<10$. Maka dapat disimpulkan bahwa dalam model regresi sudah tidak terjadi multikolinieritas antara variabel.

\section{c. Uji Heteroskedastisitas}

Uji heteroskedastisitas bertujuan untuk menguji apakah dalam model regresi terjadi ketidaksamaan variance dari residual satu pengamatan yang lain. Heteroskedastisitas menunjukan bahwa variasi variabel tidak sama untuk semua pengamatan. Pada heteroskedastisitas kesalahan yang terjadi tidak secara acak tetapi menunjukan hubungan yang sistematis sesuai dengan besarnya satu atau lebih variabel. Berdasarkan hasil pengolahan data, maka hasil Scatterplot dapat dilihat pada gambar berikut: Gambar 3

Hasil Uji Heteroskedastisitas

Sumber : Output SPSS 24.0 for Windows berdasarkan hasil penelitian, 2018
Dari grafik Scatterplot yang ada pada gambar di atas dapat dilihat bahwa titik-titik menyebar secara acak, serta tersebar baik di atas maupun dibawah angka nol pada sumbu Y. Hal ini dapat disimpulkan bahwa tidak terjadi heteroskedastisitas pada model regresi (Ghozali, 2011).

\section{Analisis Pengujian Hipotesis}

a. Analisis Regresi Berganda

Setelah dilakukan uji validitas dan reabilitas data dapat diperoleh kesimpulan bahwa model telah dapat digunakan untuk melakukan pengujian analisa regresi berganda. Berdasarkan hasil pengolahan data penelitian yang telah dilakukan, maka dapat ditunjukkan ringkasannya, seperti terlihat pada tabel di bawah ini:

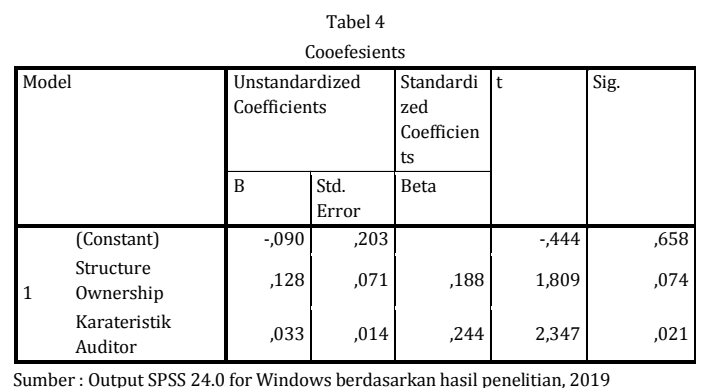

Berdasarkan hasil uji regresi berganda yang telah dilakukan dengan menggunakan SPSS 24 for Windows, dapat dibuat persamaan sebagai berikut:

$$
Y=-0,090+0,128 X 1+0,033 X 2
$$

Artinya :

1) Variabel $X 1$, hasil $t$ hitung $=1.809$ dan $t$ tabel 1,668 dengan nilai signifikansi = 0,07 , jadi dapat dilihat bahwa t- hitung $>t$ tabel dan nilai signifikansi $<0,10$. Dengan demikian hasil uji $t$ menyatakan bahwa $\mathrm{H} 1$ diterima yang artinya variabel X1 secara parsial berpengaruh signifikan terhadap tax avoidance.

2) Variabel $X 2$, hasil t hitung $=2.347$ dan $t$ tabel 1,668 dengan nilai signifikansi = 
0,02 , jadi dapat dilihat bahwa t hitung $<\mathrm{t}$ tabel dan nilai signifikansi $<0,05$. Dengan demikian hasil uji $t$ menyatakan bahwa $\mathrm{H} 1$ di tolak yang artinya variabel $\mathrm{X} 2$ tidak berpengaruh secara parsial terhadaptax ovoidance.

3) Konstanta $=-0,09$ yang berarti bahwa secara keseluruhan menjelaskan bahwa Structure ownership dan Karatersitik auditor yang baik maka tindakan tax avoidance dapat ditekan.

b. Uji Koofesien Determinasi R2 (Koefisien Determinasi)

Menurut Ghozali (2011) untuk menentukan seberapa besar variabel independen dapat menjelaskan variabel dependen, maka perlu diketahui nilai koefisien determinasi (Adjusted RSquare). Berikut ditampilkan dalam tabel Determinasi R2 sebagai berikut:

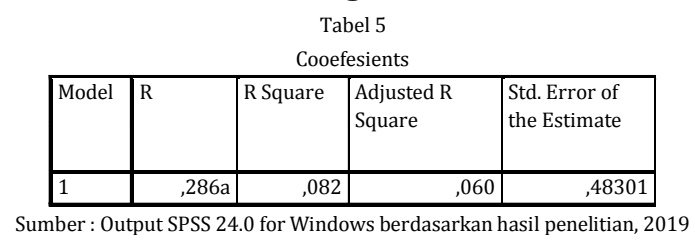

Berdasarkan tabel 5 diatas di peroleh besarnya nilai R 0,269 atau 26\%, nilai Adjusted Square adalah 0,06 yang berarti bahwa kontribusi variabel independen dengan variabel dependen di masa yang akan datang adalah sebesar 0,06 atau $6 \%$ dan sisanya $94 \%$ dijelaskan oleh variabel lain diluar variabel yang diuji.

\section{c. Uji Signifikansi Parameter Individual} (Uji t Statistik)

Uji statistik $t$ menunjukkan seberapa jauh pengaruh satu variabel independen (penjelas) secara individual mampu menerangkan variasi variabel dependen (terikat). Jika nilai t-hitung $(+)$ $>(+)$ t-tabel atau t-hitung $(-)<(-)$ t-tabel maka variabel independen secara individu berpengaruh terhadap variabel
dependen.Tingkat signifikansi yang digunakan adalah 5\%. Dari hasil program SPSS yang dilakukan mengestimasi data pada tabel 6 diatas sehingga diperoleh :

1) Variabel $X 1$ (Structure Ownership) memberikan nilai koefisien parameter (t-hitung) sebesar 1.809 dengan tingkat signifikansi $0,07 \quad(<0,10)$. Hal ini berarti H1 diterima (Hair, 2017) sehingga dapat dikatakan bahwa Structure Ownership berpengaruh Positif dan signifikan terhadap Tax Avoidance karena tingkat signifikansi yang dimiliki variabel Structure Ownership > 0,10 $(0,07<0,10)$ dan nilai t-hitung $>1,668(1.809>1,668)$.

2) Variabel $X 2$ (Karateristik Auditor) memberikan nilai koefisien parameter sebesar dengan tingkat signifikansi $0,02 \quad(<0,05)$. Hal ini berarti $\mathrm{H} 1$ diterima sehingga dapat dikatakan bahwa karateristik auditor berpengaruh psotif dan signifikan terhadap tax avoidance karena tingkat signifikansi yang dimiliki variabel karateristik auditor $<0,05(0,02>0,05)$ dan nilai thitung $>1.668$ (2.347 > 1,668).

\subsection{Pembahasan}

Berdasarkan hasil penelitian yang menguji pengaruh Structure Ownership dan Karateristik Auditor terhadap tax avoidance yang telah diuraikan di atas, maka ada beberapa hal yang dapat dijelaskan dalam penelitian ini, yaitu sebagai berikut:

1. Structure Ownership terhadap Tax Avoidance

Hasil penelitian menunjukkan bahwa terdapat pengaruh positif dan signifikan secara parsial antara Structure ownership terhadap Tax avoidance. Dapat dikatakan bahwa Kepemilikan institusional perusahaan yang diukur 
dengan persentase jumlah saham yang dimiliki sehingga besar kecilnya saham yang dimiliki entitas agar dapat meningkatkan pengawasan terhadap agent dalam menjalankan entitas sehingga mengurangi tindakan yang berlebihan dari seorang manajer perusahaan. Untuk itu biasanya institusi menyerahkan tanggung jawab kepada devisi tertentu untuk mengelola investasi perushaaan. Keberadaan institusi yang memantau secara profesional perkembangan investasinya menyebabkan tingkat pengendalian terhadap tindakan manajemen sangat tinggi sehingga potensi dapat ditekan.

Investor institusional sering disebut sebagai investor canggih,Rajgopal dan Venkatachalam(1998) dalam Komsiah(2005) menyatakan bahwa investor institusi merupakan investor yang aktive melakukan monitoring terhadap manajemen karena investor institusi pada umumnya mmemiliki saham untuk jangka panjang Tjager,et al(2003),mengutip para penganjur teori keagenan(agency theory)mengatakan bahwa para dewan (yakni para agen yang mewakili para pemegang saham) secara rasional akan bertindak bagi kepentingan mereka,dan bukan dengan bijaksana dan adil bertindak bagi kepentingan para pemegang saham .Oleh sebab itu diperlukan suatu sistim cheks and balance untuk mencegah potensi penyalahgunaan kekuasaan.

Penelitian ini sejalan dengan penelitian yang dilakukan cahyono et al, 2016 yang menemukan bahwa kepemilikan institusional berpengaruh terhadap tax avoidance.

2. Karateristik Auditor terhadap Tax avoidance

Hasil penelitian menunjukkan bahwa terdapat pengaruh positif dan signifikan secara parsial antara Kararateristik auditor terhadap tax avoidance, sehingga dapat dikatakan bahwa auditor yang memperoleh audit fee lebih tinggi memiliki kompleksitas yang lebih tinggi dalam melaksanakan tugasnya. Auditor tidak hanya memeriksa laporan keuangan perusahaan, namun juga menyediakan jasa lain seperti mencari celah untuk menghindari pajak. Hal tersebut didiukung oleh Surat Keputusan Ketua Umum Institut Akuntan Publik Indonesia (IAPI) No.KEP.024/IAPI/VII/2008 menyatakan tingkat keahlian, independensi dan tanggung jawab yang melekat pada pekerjaan merupakan komponen dalam menetapkan audit fee oleh seorang akuntan publik. Auditor yang memiliki kompetensi tinggi dan independen menghasilkan kualitas audit yang lebih baik dan menetapkan fee yang lebih tinggi pada perusahaan clien. Kualitas audit yang baik menyulitkan perusahaan untuk melakukan agresivitas pajak. Auditor eksternal dapat menyediakan jasa khusus pelayanan pajak melalui konsultan pajak untuk memberikan pelayanan pada kliennya (Mc Guire et al, 2012).

Penelitian ini sejalan dengan Penelitian Maharani (2015) dan Antonio et al (2014) menyebutkan audit fee berpengaruh positif pada tax avoidance, dimana tax avoidance adalah indikator agresivitas pajak

\section{PENUTUP}

\subsection{Kesimpulan}

Berdasarkan hasil penelitian dan analisis data yang telah diuraikan di bab pembahasan, dapat diambil kesimpulan sebagai berikut:

1. Structure Ownership berpengaruh positif dan signifikan terhadap tax avoidance, hal ini berarti institusi 
menyerahkan tanggung jawab kepada devisi tertentu untuk mengelola investasi perushaaan. Keberadaan institusi yang memantau secara profesional perkembangan investasinya menyebabkan tingkat pengendalian terhadap tindakan manajemen sangat tinggi sehingga potensi dapat ditekan.

2. Karateristik Auditor berpengaruh positif dan signifikan terhadap tax avoidance, hal ini berarti bahwa auditor yang memperoleh audit fee lebih tinggi memiliki kompleksitas yang lebih tinggi dalam melaksanakan tugasnya yaitu memeriksa laporan keuangan perusahaan, namun juga menyediakan jasa lain seperti mencari celah untuk menghindari pajak.

\subsection{Saran}

Berdasarkan pembahasan pada hasil penelitian, berikut ini disampaikan beberapa saran sebagai berikut:

1. Perusahaan go public harus berhati hati dalam melakukan tindakan tax avoidance karena mengandung resiko yang sangat tinggi dengan peraturan perpajakan di Indonesia

2. Untuk peneliti selanjutnya, bisa menambahkan variabel lain untuk menilai tindakan tax avoidance.

\section{DAFTAR PUSTAKA}

Agus. (2015, August Monday). Karakteristi Auditor. Retrieved from www.coursehero.com:https://ww w.coursehero.com/file/pr0jl1/4Karakteristik-Kriteria-AuditKarakteristik-kriteria-yang-baikmencakup-hal/

Alit., I. G. (2014). Pengaruh Corporate Governance, Profitabilitas dan Karakteristik Eksekutif Pada Tax
Avoidance

Perusahaan

Manufaktur. . EJurnal Akuntansi Universitas Udayana. Vol. 9. No. 2, 16-31.

Ariani. (2012). Karakteristik Komite Audit, Eksternal Auditor, dan Audit Report Lag. Proceeding Seminar Nasional Hasil Penelitian STIE.

Ariany. (2012). Karakteristik Komite Audit, Eksternal Auditor, dan Audit Report Lag. Proceeding Seminar Nasional Hasil Penelitian STIE.

Bagus. (2010). The International Tax Compact. Retrieved from www.ajarekonomi.com:

htps://www.ajarekonomi.com/20 15/12/memahami-tax-evasiondan-tax-avoidance.html

Bambang Supomo, d. I. (2009). Metodologi Penelitian Bisnis untuk Akuntansi dan Manajemen, (Pertama ed.). Yogyakarta: BPFE.

Budiman, J. \&. (2012). Pengaruh Karakter Eksekutif terhadap Penghindaran Pajak (Tax Avoidance). 43.

Darwis. (2012). Pengaruh Structure Ownership dan Karaktersitik dalam Kepemilikan Instutusional, Kepemilikan Manajerial terhadap Tax Avoidance. Economic and Bussiness, 60-68.

Ghozali, I. (2011). "Aplikasi Analisis Multivariate Dengan Program SPSS". Semarang: Badan Penerbit Universitas Diponegoro. .

Herdiyanto, D. G. (2015). Pengaruh Tax Avoidance Terhadap Nilai Perusahaan. . Diponegoro Journal Of Accounting. Volume 4, Nomor $3,1-10$

IAI. (2001). Standar Profesional Akuntan Publik. Jakarta: Ikatan Akuntan Indonesia (IAI).

Indrayagus. (2009). Tax Planning, Tax Avoidance, dan Tax Evasion di 
Mata Perpajakan Indonesia. In Inside Tax (p. 8). Jakarta.

Jensen, M. a. (1976.). "Theory of Firm: Managerial Behaviour, Agency Cost and Ownership Structure". pp. pp. 305-360.

Kemenkeu. (2017, September 3). Diambil kembali dari https://www.kemenkeu.go.id: https://www.kemenkeu.go.id/pu blikasi/berita/wamenkeuinformasikeuangan-pentinguntuk-tingkatkankepatuhanmembayar-pajak/

KNKG. (2006). Pedoman Umum Good Corporate Governance Indonesia. Jakarta.

Kurniasih, T. \&. (2013). Pengaruh Return On Assets,Leverage, Corporate Governance, Ukuran Perusahaan Dan Kompensasi Rugi Fiskal Pada Tax Avoidance. . Buletin Studi Ekonomi, Volume 18, No. 1, .

Ninik. (2017). Pengaruh Fee Audit, Audit Tenure, Rotasi Audit dan Reputasi Auditor Terhadap Kualitas Audit di Kantor Akuntan Publik. Ekonomi dan Bisnis.

Nugraha, R. A. (2019). "Pengaruh Corporate Ownership, Karakteristik Eksekutif Dan Intensitas Aset Tetap Terhadap Tax Avoidance. 60-65.

Nurul Mutmainnah, R. W. (2013). Nurul Mutmainnah, Ratna Wardhani. Jurnal Akuntansi dan Keuangan Indonesia, Vol 10, No 2 (2013), 40-50.

Oktaviyani, R. a. (2017). Effect of Solvency, Sales Growth, and Institutional Ownership on Tax Avoidance with Profitability as Moderating Variables in Indonesian Property and Real Estate Companies. . Binus Business Review, , 183-188.
Paulus, M. (2007). Categorizing International Tax Planning. Fundamentals of International Tax Planning. IBFD, 66-69.

Pengaruh Corporate Governance, Profitabilitas dan Karakteristik Eksekutif Pada Tax Avoidance Perusahaan Manufaktur. (2014). Jurnal Akuntansi Universitas Udayana. Vol. 9. No. 2. , 16-31.

Siagian, G. d. (2011). Agency Teory. Economic and Business.

Siregar, S. V. (2005). Pengaruh Struktur Kepemilikan. Ukuran Perusahaan.

Sudana, I. M. (2011). Manajemen Keuangan Perusahaan. Jakarta: Erlangga.

Sugiyono. (2015). Metode Penelitian Kombinasi (Mix Methods). Bandung : Alfabeta.

Suharto. (2015). Agency Theory dalam prinsip manajer. Yogyakarta: Salemba Empat.

Sukirni, D. (2012). Kepemilikan Manajerial, Kepemilikan Institusional, Kebijakan Dividen dan Kebijakan Hutang Analisis terhadap Nilai Perusahaan. Accounting Analysis Journal. Vol. 1, No. 2, 1-12.

Wahab. (2012). Determinants of capital structure of Malaysian property developers. Journal of Scientific Research, 8, 1013-1021.

Winata, F. (2014). Pengaruh Corporate Governance Terhadap Tax Avoidance pada Perusahaan yang Terdaftar di Bursa Efek Indonesia Tahun 2013. Tax dan Accounting Review. Vol. 4. No. 1. , 1-11.

Yasser. (2017). Corporate Social Responsibility and Gender Diversity: Insights from Asia Pacific: Gender Diversity, Corporate Social Responsibility. Corporate Social and 
Invoice: Jurnal Ilmu Akuntansi

p-ISSN: 2714-6359 e-ISSN: 2714-6340

Vol. 2 Nomor 1 Maret 2020

Enviromental Management, 3, 143.

Yasser, Q. M. (2017). The Impact of ownership structure on financial reporting quality in the East. International Journal of Organizational Analysis, 25. 